\title{
AN INVESTIGATION THE RELATIONSHIP BETWEEN ORGANIZATIONAL CULTURE AND EXTERNAL CUSTOMER SATISFACTION ORIENTATION \\ (An Empirical Study of four stars hotels in Tripoli- Libya)
}

Yousef Ali Mohamed Zaroug ${ }^{1}$, Armanu Thoyib ${ }^{2}$, Djumilahv Hadiwidjojo ${ }^{3}$, and Solaimun ${ }^{4}$ ${ }^{1,2,3,4}$ Department of Management, University of Brawijaya

\begin{abstract}
Purpose - The objective of this research was to examine the relationship existed between the variables; Customer satisfaction Orientation and organizational culture within an internal customer orientation and internal service quality, and determine the nature of the interaction between dimensions of the customer satisfaction orientation and cultural dimensions of Libyan hotels.
\end{abstract}

Design/methodology/approach - This research depended on the questionnaires were designed for the purpose the respondents of the study were 115 managers within 23 hotels in Tripoli.

Findings - The result of this research showed that there was a significant relationship between scores of the organizational culture and customer satisfaction orientation in Libyan hotels.

Practical Implications - There were a significant relationship between organizational culture and internal customer satisfaction and internal service quality.

Originality/value - This research also proves a significant effect of internal customer orientation and internal service quality on external customer satisfaction orientation in the Hotels sector in Libya. In addition, a number of managerial implications of the findings were further were explored in this study. Keywords - organizational culture, internal customer orientation, internal service quality, and external customer satisfaction orientation.

\section{INTRODUCTION}

Generally speaking, there are deep roots of organisational culture through the twentieth century, especially after global II war, corporations became thinking to study and analyse their cultures, because it is natural for individuals and their first cultures "local culture" to gain from the social environment that they live in(Abridah, 2012). Thus, companies develop training programs to guide these values and beliefs in line with their principles. In addition, unify the cultural style of the institution and make it as the basic

Vol. 28, No. 2 August 2020

(C) Centre for Indonesian Accounting and Management Research Postgraduate Program, Brawijaya University 
principles governing the relations between work and organization. National culture means that a social system which contains a number of people, who are sharing several of features such as, costumes, traditions, language, behavioural speech, religion, and pattern of public life (Abubaker, 2007). According to Hofstede (2001)It is a collective system as a control of minds that is represented by a specific group of people. However, Lim (2002) sees a culture model consisting of four dimensions: the distance of power, avoiding uncertainty, individuality, and masculinity.

There is no doubt, that two above definitions of local culture showed that, national culture considered, a number of values and beliefs and behaviours that overlap between them and adopted by a certain team of people to become a routine, continuous. While Horowitz (2009) focused on the study and analysis of the model of cultural consensus, which combines both the social culture and the culture of the organization as well as consumer culture, the analysis of the relationship, and also the extent of influence between them if positive or negative.

Cameron (2018)Reported that, organizational culture can be measures statistically to identify trends, attitudes and psychological trends of individuals at the group level, while consumer culture can be analyse by consensus in conjunction with explanatory methods to help researchers obtain a result that reflects the reality of these cultures and their interdependence, impact and strength. In general, we can conclude that must note the features that connect the members of society often homogeneous, the relationships among its members characterized by strength and harmony.

M. C. Davidson (2003)sees that, the important step to invest in a new market should analyse the cultural environment of the community and determine what is acceptable and unacceptable of ideas, products and services before entering and investing or design products. Moreover, the process of activating the organisational culture is similar to the social upbringing of the child exactly, for this important factor, the work relationships should build based on the interest of the company and employees as partners have strategic objectives and believing and support their organisational culture.

Whether, (Desson \& Clouthier, 2010) argued that, these values have learned and taught to individuals since the beginning of the firms. However, the founders and managers are playing an important role in the creation of customs, traditions and methods of work, especially in the periods of initial formation of the organization, where the vision and philosophy they believe in play a large role in the development of cultural values in the firm. There is no doubt that small organizations in their establish stages of development facilitate the process of influencing and imprinting, imposing the vision, and instilling values in society. Whereas, organizations rely on formal means to control employee behaviour by organizing procedures, instructions, and developing models and employees.

On the other hand, these policies and procedures lead to the consolidation of the culture of individuals. As well as to enhance the relationships between them within the organization. Surely, that is in order to ensure the team's coherence and adoption of these policies in order to achieve the strategic objectives of the organization. Alshibani and Alatwi (2010), reported that there are more than 100 companies entered the competition at the

\section{Vol. 28, No. 2 August 2020 \\ (C) Centre for Indonesian Accounting and Management Research \\ Postgraduate Program, Brawijaya University}


beginning of the 1900s, till now just remained 16 firms because they ignored the developing side of their goods and services, according to fortune journal more than $46 \%$ of 500 great companies has cancelled from the list for the above reason. In addition, the companies have ignored a very important factor, which is keeping up with change. The organizational culture has summed up in a set of values, beliefs, attitudes, managerial policies, and language that define the common identity and societal sense of the organisation. However, if organisations develop their culture in order to provide employees with a distinct identity and common understanding of their goals, principles and the treatment of its works. Furthermore, that has done through a set of solid and soft elements, which influence the culture of the organisation (Agbejule, 2011). Whereas, the solid elements are the organisational structure: Specific systems, rules, and procedures, In addition, soft elements which represented in the style, skills, values, principles, and finally symbols and the particular stories of the organisation. However, there are several scientists of administration are seeing that the strong relationship between firm's culture and the consumer satisfaction (Gillespie, Denison, Haaland, Smerek, \& Neale, 2008).

Otherwise, the relationship between corporates and their customers may effect positively or negatively by several parts, which moderated through a number of an important elements such as customer relationship marketing and internal services quality.In hotels industry, the external customer satisfaction considers a centre point that be oriented the whole team's efforts. However, a number of researchers such Kao, Tsaur, and Wu (2016) see that the effectiveness of organisational culture on consumer behaviour could represent a significant change in positive or negative side of customer satisfaction.

\section{LITERATURE REVIEW}

\section{Organisational culture concept:}

The organisational culture; this concept has emerged clearly and repeatedly in the research literature of the institutions of the administration since 1981 and has not stopped growing since then, as organisational behavioural scientists continued to adopt the culture of the organisation as an input to analysis. However, there are many definitions of the culture of the organisation according to the view adopted by researchers such as, (Tsoukatos \& Rand, 2007)(Willcoxson \& Millett, 2000), (Pantouvakis \& Bouranta, 2013). Indeed, some of whom defined it through its constituents, some of them defined it the impact of those elements, and components on the behaviour of workers and some of them defined it through its functions.

An integrative definition of the concept of "O.C" could obtained by examining the different definitions presented by the researchers, such as Kim Jean Lee and $\mathrm{Yu}(2004)$ organisational culture is considered a pattern of assumptions developed, invented or discovered by a group.Tsoukatos and Rand (2007) Defined that culture is a social system for programming the minds of a certain group of people, which distinguished them from other groups.

Vol. 28, No. 2 August 2020

(C) Centre for Indonesian Accounting and Management Research Postgraduate Program, Brawijaya University 
Whereas, Wang (2012b) considered that the Organizational culture represented in a ritual, company values, communication, corporate environment, ceremonies, figures and symbols. While, learning how to deal with its problems in external adaptation and internal integration that went well enough to be considered valuable and therefore should be taught to new individuals as the right way of perception and thinking for those problems (Senarathna, Warren, Yeoh, \& Salzman, 2014). However the most common definition that reflect the understanding of "OC" concept, and further most of authors agreed is "organizational culture is defines as a group of customs, traditions, language, concepts and administrative procedures such as rewards, punishment, relationships, friendship, respect, working methods and other standards that may differ from those found in other organizations".

Historically, national culture consider the background of organisational culture, Tsoukatos and Rand (2007) defined that culture is a social system for programming the minds of a certain group of people, which distinguished them from other groups. Whereas, organizational culture is defines as a group of customs, traditions, language, concepts and administrative procedures such as rewards, punishment, relationships, friendship, respect, working methods and other standards that may differ from those found in other organizations (Willcoxson \& Millett, 2000). Whereas, Pantouvakis and Bouranta (2013) believes that organizational culture represents the backbone of the organization in the management of human resources because of-of its profound impact on people's attitudes, tendencies, positions and performance.

Generally, there are many theories that dealt with the concept of organizational culture over time for each of its purposes and philosophy in the perception of different views of existing companies where researchers have taken more and more of time to create and analyse. However, several authors have explained these theories, such as Ehrhart, Schneider, and Macey (2013) whom supposed two common theories:

Theory of Transactions cost:

According to this theory, companies are subject to effective contractual tools and frameworks, meaning that employees are interested in arranging themselves and contracting within the enterprise rather than contracting in the market (Weeks \& Galunic, 2003). However, this theory has been interpreted by (Ferreira \& Li, 2010) as a form of traditional cultural dealings of the company, that is, transactions are carried out within the company and its administrative limits. However, sometimes focused transactions with external limbs that exceeds the focus on the two extremes of "hierarchy and market" this is Prove that transactions within the boundaries of the company are evidence of market failure and focus on the model supply and demand.

Theory of Knowledge:

This theory emerged in the late twentieth century, the summary of this theory is that the company prefers to integrate and apply knowledge of the economic activities, which in turn is the reason for the existence of the company (Kummerow \& Kirby, 2013). This theory holds that the company exists, that because it is more successful than the market for the integration and application of knowledge (Weeks \& Galunic, 2003).

Vol. 28, No. 2 August 2020

(C) Centre for Indonesian Accounting and Management Research

Postgraduate Program, Brawijaya University 
(Bitsani, 2013; Hofstede, Hofstede, \& Minkov, 2010) reported that, for the cognitive school, culture is seen as an intellectual framework of knowledge or as models acquired through the beliefs, customs and perceptions through which a number of the staff works satisfactorily and acceptable to their fellow group members or others from other groups. Moreover, the cognitive theory allows individuals to interact logically based on the individual concept of members of these human groups in the domain.

In fact, there are no obvious differences between these two theories, There is a convergence of views on these two theories, indeed they are giving the same results, and further, they are sharing many hypotheses. However, the worth mentioning that organizations and companies in all sectors, the reason for their presence, truly they are providing some incentives and benefits to their members. The development of organizational culture throughout history has its origins from the early 19th century (Weeks \& Galunic, 2003).

As a number of researchers considered that, the organizational culture to be an integral part of the community culture, which in turn depends heavily on the types of companies and the diversity of their activities. However, the organizational culture today is not much different than it was decades ago, despite the attempts of a number of researchers such as (Hofstede, 2018), (Kao et al., 2016), (Hofstede, 1980) and (Desson \& Clouthier, 2010). On the other hand, they often agreed that the organizational diversity is an extension of the culture of the prevailing community as the organization finds itself obliged to adapt to the values of the community that operates in it. (Hughes, 2015) believes that, the culture of organizations has developed and that companies are of a cultural nature in the original, which may differ cultural patterns from one company to another.

The concept of internal customer orientation is one of the modern marketing concepts that emerged in the 1980s, because of the development witnessed by marketing concepts in general. However, when most organizations realized that relations with external customers and achieving their satisfaction might not be possible without going to the internal customer and developing the relationship with him through know his needs, wishes, and work to provide them to reach a high degree of job satisfaction. (Anosike \& Eid, 2011).

\section{Internal Customer Orientation concept:}

There is little agreement on the concept of relationship marketing, and it has resulted in it doing more than its understood to have done more than that to him to redirect the provide efforts towards existing and potential customers after investigating them in scientific ways. Moreover, there is a view of some of the marketing experts about the concept of relationship marketing as it is concerned with the circumstances of each individual customer, an entitlement to a challenge. Accurately, that challenges the most value by giving the customer the priorities of the information participants to avoid deceive the customer by saying and selling his real involvement by communicating and sharing information. In general, there are many definitions of marketing relationships, including the following:

Vol. 28, No. 2 August 2020

(C) Centre for Indonesian Accounting and Management Research Postgraduate Program, Brawijaya University 
Kotler and Keller (2009) Defined the concept of ICO which is the ideal choice for qualified workers, develop their skills and provide them with the services they need and encourage them. In order achieving their satisfaction and loyalty to the organisation. Meanwhile, Varey and Lewis (2000) defined ICO as a philosophy of conducting marketing practices on personnel and recruiting competencies and retaining them as internal customers. While, (Sharp, 2013) sees that, the ICO is the process of selecting and motivating qualified employees while retaining them, provided that their skills and abilities are consistent with the nature of the work they have performed.M. Davidson (2008)Was defined that,ICO, is an implementation of the marketing's philosophy and practices on individuals' workers who serve customers.

On the other hand, Anosike and Eid (2011) sees that the attention to the employees as an internal customer so far has not exceeded the levels of the institutional application, but is a slogan in which it hesitates, without extending to the marketing as a marketing doctrine at the high levels of the firm. Furthermore, the perception of employees as a form of customers within the institution, and he summarised that internal marketing simply means, a need the corporate management to effectively market its products within the organization to meet the expectations of internal customers or beyond their expectations.

Based on the above in the definitions that some activities become apparent to the basis of the internal customer orientation, such as polarisation, motivation, development, and although it does not differ from those definitions mentioned and adopted by human resources management literature. However, they emphasize the specificity of human resource management in organizations, services, and the need for organizations to treat their employees in the way they want them to be treated. Accurately, the meaning of this is that the organization treats its employees as an internal market and thus tries to influence them in the same way that affecting the external client response.

Conclude that, recognizing the importance of the role of the employees in the marketing of the service requires that the administration to consider them as the first market for the organisation and that their functions represent internal products which must be designed and developed in accordance with their needs and desires and thus increase their satisfaction.

The importance of ICO:

ICO has vital importance in satisfying the needs and desires of the employees and achieving the objectives of the institution, as it works to provide an internal environment that supports the morale and develops positive behaviours toward the institution. (Kotler \& Keller, 2009) .

Fattah and Twigg (2017)Said that, Internal customer orientation concept considers as an administrative approach that aims to reach customers by developing and motivating the organization's personnel to perform their duties in the best way. Definitely, this comes, as a result, of communicating with customers and applying the philosophy of management and quality in the performance of services by all members of the organisation in a way that achieves quality and customer satisfaction. 
In general, this means that the adoption of the approach and philosophy of internal customer orientation in the organisation is the way the company moves to its external markets and the tool through which it promotes the position of competition in these markets. In addition, this reflected positively on the performance and profitability of the organization and its objectives, and internal marketing is important. However, the benefits of the ICO for the organisation represented in the management of change, build a general image, the strategy of the firm (Ahmed \& Rafiq, 2003).

\section{Internal Service Quality Concept:}

The quality of internal service is a relatively recent issue compared to the quality of the external service. Moreover, it considered the level of the situation in which the service provided to customers in terms of its different dimensions, but from the perspective of providers of this service to customers (Jun \& Cai, 2010). In order to achieve customer satisfaction, it is necessary to provide high-quality services, and this is not possible only by providing internal services with a high level of quality. As well as, this is not possible without achieving job satisfaction, which is the link between the internal and external quality of service (Srivastava \& Prakash, 2019).

The importance of internal services quality:

The importance of internal services quality considering as a complementary process leads to increasing the quality of service to the final customer. As a result, customer satisfaction will achieve by external service quality that was the outcome of the internal service quality, which is the main objective of the company. However, the quality of the internal service means cooperation between the various departments of the company. Moreover, internal service is a way to increase the level of customers' satisfaction. Definitely, when the employee satisfaction increases productivity will increase as well, and therefore increase the proportion of profits of the company and the rates of satisfaction of customers (E. Susanti, E. T. Sule, \& H. Sutisna, 2015).

The quality of service: It is suitable for customers to expect from the hotels' service provided with the actual realisation of the benefit obtained by customers because of their access to the service, so good service from the point of view of customers is consistent with their expectations (Pantouvakis \& Mpogiatzidis, 2013).Järvi (2012)Reported that, the importance of internal service quality has increased because of it's supporting the relationships between the firm and its employees. Nowadays, many companies are seeking to develop the internal quality of their services according to the needs of their employees. Moreover, this will lead to keep its customers and attract new customers.

Wang (2012a), said that, the pressure on business organisations is too great to improve the quality of the services they provide, whether these organizations are public or private. The quality of services depends mainly on the measurement criteria, which characterized by a high degree of difficulty due to its intangible.

However, E. Susanti, E. Sule, and H. Sutisna (2015) sees that, quality of service has become an important criterion to measure the performance of organizations, as it has been

Vol. 28, No. 2 August 2020

(C) Centre for Indonesian Accounting and Management Research Postgraduate Program, Brawijaya University 
subjected to many studies in order to help organizations develop their services and satisfy their customers. This indeed in accordance with the expectations of customers and their perceptions of the achieving extent their desires opposite the financial values they have paid. Further, Organizations seeks to investigate customer opinions to identify and address weaknesses and emphasize strengths and develop them.

\section{External Customer Satisfaction orientation Concept:}

Theoretically, the marketing science literature has dealt with a set of theoretical concepts of customer orientation derived from experimental reality, and marketing scientists have documented the proposed benefits. However, due to its complexity, this concept has received limited attention. Webster $\mathrm{Jr}$ (1988). Where, a number of scientists such as Webster Jr (1988), Deshpandé and Farley (1999) agreed that the concept of customer orientation is a number of beliefs and concepts that believe that the interest of the customer should be at the top of the company's concerns. In addition, taking into account not to ignore or exclude other stakeholders involved in the marketing process, in order to develop the company In order to survive and be a profitable organization in the long run, however, there are a number of researchers E.gNarver and Slater (1990), Day (1994). Agreed that, the concept of customer focus has not received sufficient attention.

Many marketing and management experts believe that it is not possible to go to the client unless it has supported by senior management such as: Bass, Stogdill, and Bass (2008), House and Podsakoff (2013), (Webster Jr, 1988) said that the beliefs and values that support customer orientation are the responsibility of the top management in particular. While the Executive Director is responsible for determining and knowing the direction Clients and the market as a driving force to make decisions related to customer orientation and focus on his needs and desires. Moreover, customer orientation is a competitive advantage that helps to strengthen the company's competitive position. Therefore, decision makers and senior officials of the organization must set organizational goals and align them with customer satisfaction policies (Homburg, Müller, \& Klarmann, 2011).

Homburg et al. (2011)Mentioned that, the ultimate goal of business operations is the customer, as the organization's survival depends on the customer. Because it is the key to the success and failure of an organization, and in order to survive, business organizations must provide products: goods or services of value to the customer. Furthermore, this is a success for them, and therefore organizations adopt directions to enable them to adopt methods of work to guide them and there is interest in their market position, and where the destination, and the level of progress? In addition, this interest is evidenced by the trend towards it, because it is now perceived to the customer as an asset but is the desired goal, and to be able to organizations to work on strategies based on the orientation of all its activities and work towards the customer. (Baumann, Elliott, \& Burton, 2012). Bowen and Chen(2001) sees that the concept of customer satisfaction is reflected in the efforts of various businesses to win the satisfaction of consumers by providing material productivity products or services.

Vol. 28, No. 2 August 2020

(C) Centre for Indonesian Accounting and Management Research

Postgraduate Program, Brawijaya University 
There are many researchers, who have exposed to the customer satisfaction, the most important of several definitions, which we have chosen. Where, Makeeva (2010) said that satisfaction is a high degree of positive sense toward quality of service, which basically depends on the level of experience and the degree of expectations that believed by the customer. Moreover, the satisfaction depends on a number of factors such as sympathy, emphasis, responsiveness, confidence prices and events that occur during the service delivery or after.According to Wilson (2002) there is a degree of ambiguity and complexity that prevents customer satisfaction from being recognized and achieved, while Bellou (2007) sees that, satisfaction as a knowledge building and psychological condition for customers that are difficult to assess or verify.

Ambrož and Praprotnik (2008) Says customer satisfaction is the extent to which services or products achieve customer expectations, however according to the appropriate criteria for their needs and wants and preventing them to get their needs from other competitors. Definitely, customer satisfaction in the hotel organizations is closely related to the level of services provided and the customer's attitude towards the brand because of the previous perceptions and accumulated experience

On the other hand, satisfaction is the positive feeling that occurs before, during and after the purchase. When a guest thinks of choosing a hotel he wants to live in, he compares in his choice in relation to the benefits obtained or promises made by the brand and settle at the hotel he deems appropriate (Bizi Mubiri, 2016).

The organizations seek to study the behaviour of customers and their attitudes to find out whether they are satisfied with their services or not. However, several studies have shown that customers who are not satisfied with the company's service quickly turn to other organizations, expect that they will meet their desires and achieve their expectations (Amiri Aghdaie \& Faghani, 2012).Furthermore, the study of customer behaviour enables the organization to identify and address the shortcomings and weaknesses, and to avoid falling into it in the future, in addition to identify and emphasize the strengths and persistence in the development(Baumann et al., 2012).

On the other hand, Bizi Mubiri (2016) sees that, the erroneous interpretation of customer perceptions and their impressions of the services provided may lead to failure to achieve the competitive advantage that the organization seeks to reach, and this negative estimate certainly will reflecting negatively on profitability and achieving targeted revenues.

However, to examine customer satisfaction this study will depend on indicators have been used by (Conrad, Brown, \& Harmon, 1997), including:

1. Attention to customer satisfaction. It means that customer satisfaction is the first goals of the company long-term strategy. In addition, for the importance of customer satisfaction, firms are giving full attention to customer relationship marketing.

2. Measuring strategies: to what extent administration examines customer satisfaction, occasionally or frequently, As well as how the company seeks to develop customer's satisfaction measurement tools. 
3. Attention to after-sales service. Additional services after providing the main service to the customers, and what is the level of these services quality.

4. Customer service: this focussing on the measurement of customer service quality and what the mangers tools to develop measurement tools of customer service regularly.

\section{Framework}

Figure 1 the framework of the study

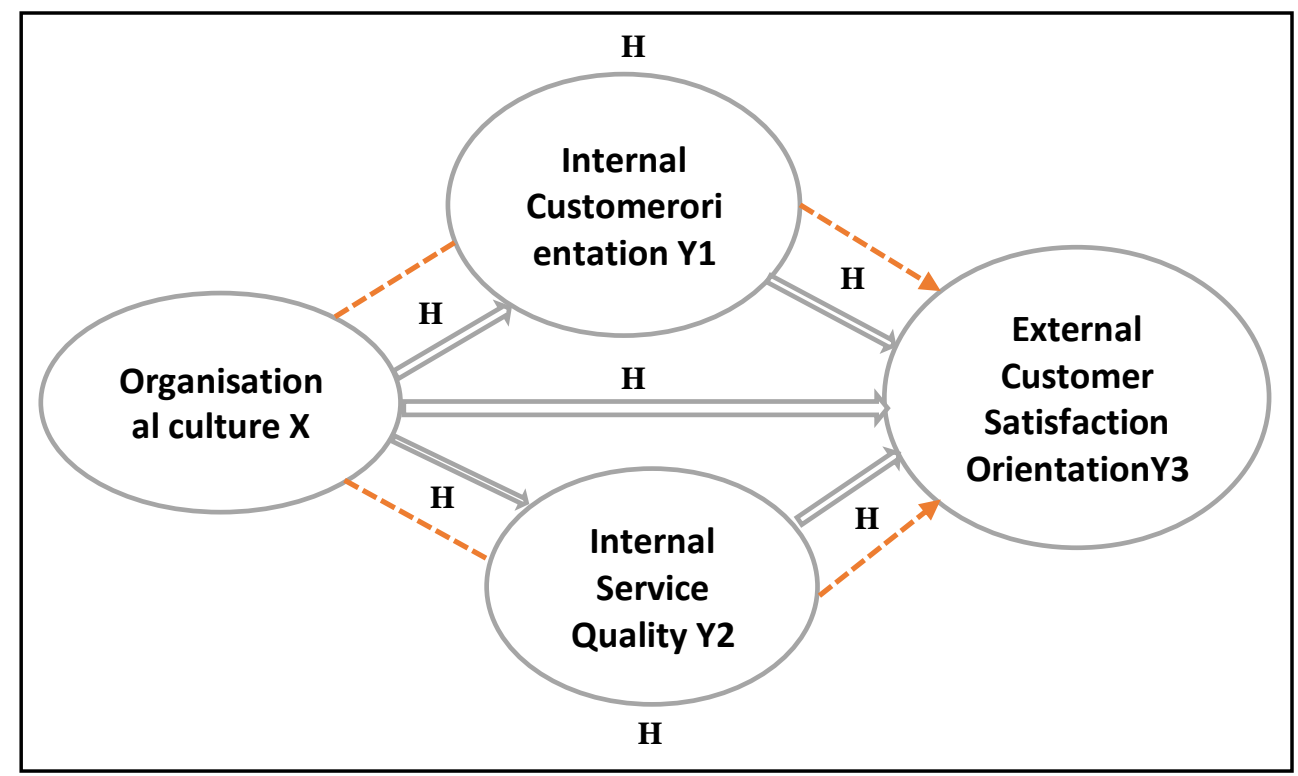

H1 There is a positive significant effect of Organisation culture on External customer satisfaction orientation.

H2 There a positive significant effect of organisation culture on Internal customer orientation.

H3 There a positive significant effect of Organisation culture on internal services quality provided.

H4 There is a positive significant effect of the Internal customer orientation on external customer satisfaction orientation.

H5 There is a positive significant effect of internal services quality on external customer satisfaction orientation.

H6 There is a positive significant effect of Organisation culture on external customer satisfaction orientation mediating by Internal customer orientation.

$\mathrm{H} 7$ There is a positive significant effect of Organisation culture on external customer satisfaction orientation mediating by internal services quality. 


\section{METHODOLOGY}

The location of the study is hotels sector in the capital of Libya "Tripoli" Libyan Hotels through year 2019.

The population of this study is all of Libyan private hotels in the capital of Libya "Tripoli" identified in the categories of three and four-star hotels through the period of 2019, which count 23 three and four-star hotels. In addition, this number according to statistics of the Libyan Tourism Ministry for the year 2017.

The study depended on Huber and Power (1985), and Conrad et al. (1997) collecting data that related of the study from the senior management and executive members of the studied organizations. However, this is because identifying managers as respondents meet the requirements of taking the data required for the study, which is more accurate and effective.

Furthermore, the samples included managers, assistants, and the heads of departments of three and four-star hotels in Tripoli: 23 hotels, each hotel has represented in five samples. Which counted the total of the research sampling $=115$ respondents.

\section{FINDING}

\section{Demographiccharacteristics}

This research has been depended on 115 respondents as a total sample, Table 1 showing the demographic characteristics of respondents.

Table 1.Summary of demographic characteristics

\begin{tabular}{|l|c|c|}
\hline \multicolumn{2}{|c|}{ Demographic characteristic } & Total respondents in \% (n=115) \\
\cline { 2 - 3 } & Male & $\mathbf{8 7}$ \\
\hline Gender & Female & 28 \\
\hline \multirow{3}{*}{ Age } & & $100 \%$ \\
\cline { 2 - 3 } & Less than 20 & 3 \\
\cline { 2 - 3 } & From 20 to 35 & 21 \\
\cline { 2 - 3 } & From 35 to 50 & 60 \\
\hline Total & From 50 to 60 & 31 \\
\hline \multirow{3}{*}{ Educational level } & & $100 \%$ \\
\cline { 2 - 3 } & Secondary school & 14 \\
\cline { 2 - 3 } & Bachelor & 36 \\
\hline Total & Master & 46 \\
\hline \multirow{3}{*}{ Experience } & Doctoral & 19 \\
\cline { 2 - 3 } & & $100 \%$ \\
\cline { 2 - 3 } & Less than 5 years & 5 \\
\cline { 2 - 3 } & From 5-10 years & 30 \\
\hline Total & From 10-20 years & 55 \\
\hline
\end{tabular}

Vol. 28, No. 2 August 2020

(C) Centre for Indonesian Accounting and Management Research Postgraduate Program, Brawijaya University 


\begin{tabular}{|l|c|c|}
\hline \multirow{2}{*}{ Nationality } & Libyan & $\mathbf{9 5}$ \\
\cline { 2 - 3 } & Foreigner & $\mathbf{2 0}$ \\
\hline Total & & $\mathbf{1 0 0 \%}$ \\
\hline
\end{tabular}

According to Table, 5.1 Male was counts as the majority with total number 87 people $(75.7 \%)$ it means that the culture of hospitality organisations in Libya is taking the predominantly masculine character, especially in administrative work. While, must of respondents aged between 35-50 years with percentage $52.2 \%$ it means that most of the employees in the Libyan hospitality institutions have the full experience and physical ability to perform their tasks and make the right decisions at the right time. The most respondents were holding master degree 46 people that counted $40.0 \%$ of total respondents it means that most of Libya hotels managers' are qualified, and they can search for the appropriate theories of organisational culture to their organisations. In addition, 55 respondents have experienced from 10-20 years as the majority of respondents it means that most of the workers in the Libyan hotel sector have sufficient experience to enable them to accomplish tasks of appropriate quality, also means that they have good skills to deal with each other as well as dealing with customers. The number of Libyan workers was 95 people (82.6\%), and only $17.4 \%$ were foreigner. It means that the Libyan hotel sector depends mainly on the employment of Libyans rather than foreigners. In addition, the culture of the Libyan organisations includes this concept that the director should be Libyan even if there is another employee more qualified and experienced, but reap nationality.

\section{Organisational Culture}

The following data in Table 2 representation description of respondents' answers including Mean, and standard deviation of organisational culture variable (Afobunor \& Udegbe), which showed and obtained in table 2 .

Table 2summary of descriptive data of Variable Organisational Culture

\begin{tabular}{|c|c|c|c|}
\hline Indicator & Item & Mean & Std deviation \\
\hline \multirow{3}{*}{ Dominant characteristics } & Personal caring & 2.85 & 1.29 \\
\cline { 2 - 4 } & New ideas & 2.77 & 1.31 \\
\cline { 2 - 4 } & Procedures & 3.10 & 1.28 \\
\cline { 2 - 4 } & Achieving work & 3.03 & 1.37 \\
\hline Overall Dominant characteristics & & $\mathbf{2 . 9 3}$ & $\mathbf{1 . 3 1}$ \\
\hline \multirow{3}{*}{ Organizational leadership } & Facilitation & 2.95 & 1.38 \\
\cline { 2 - 4 } & Supporting & 2.85 & 1.30 \\
\cline { 2 - 4 } & Productivity & 2.93 & 1.36 \\
\cline { 2 - 4 } & Coordination & 2.84 & 1.34 \\
\cline { 2 - 4 } & & $\mathbf{2 . 8 9}$ & $\mathbf{1 . 3 4}$ \\
\hline Overall Organizational leadership & & &
\end{tabular}

Vol. 28, No. 2 August 2020

(C) Centre for Indonesian Accounting and Management Research

Postgraduate Program, Brawijaya University 


\begin{tabular}{|c|c|c|c|}
\hline \multirow{4}{*}{ Staff management } & Participation & 2.99 & 1.40 \\
\hline & Discrimination & 2.97 & 1.32 \\
\hline & Performance & 3.09 & 1.34 \\
\hline & Competition & 3.10 & 1.30 \\
\hline \multicolumn{2}{|l|}{ Overall Staff management } & 3.04 & $\mathbf{1 . 3 4}$ \\
\hline \multirow{4}{*}{ Organizational coherence } & Trust & 3.10 & 1.36 \\
\hline & Development & 3.02 & 1.30 \\
\hline & Rules & 3.08 & 1.39 \\
\hline & Achieve goals & 3.18 & 1.33 \\
\hline \multicolumn{2}{|c|}{ Overall Organizational coherence } & 3.10 & 1.34 \\
\hline \multirow{4}{*}{ Strategic focus } & Human development & 2.77 & 1.43 \\
\hline & Explore opportunities & 3.02 & 1.47 \\
\hline & Efficiency & 3.08 & 1.35 \\
\hline & Competitive actions & 2.76 & 1.44 \\
\hline \multicolumn{2}{|l|}{ Overall Strategic focus } & 2.90 & 1.42 \\
\hline \multirow{4}{*}{ Standard of excellence } & Human aspects & 3.01 & 1.40 \\
\hline & Distinguished services & 2.94 & 1.37 \\
\hline & Market-share & 2.84 & 1.42 \\
\hline & Production costs & 2.81 & 1.36 \\
\hline \multicolumn{2}{|l|}{ Overall Standard of excellence } & 2.90 & 1.38 \\
\hline \multicolumn{2}{|l|}{ Overall Organisational culture } & 2.96 & 1.36 \\
\hline
\end{tabular}

According to the descriptive data in table2 Organizational coherence $(M=3.10, S . D=1.34)$, it was the higher and important dimension in organisational culture in Libyan hotels institutions, followed by Staff management $(M=3.04, \quad S . D=1.34)$, Dominant characteristics $(M=2.93$, $\mathrm{S} . \mathrm{D}=1.31)$, meantime Strategic focus $(\mathrm{M}=2.9, \mathrm{SD}=1.42)$, and Standard of excellence $(M=2.9, \quad S . D=1.38)$, Organizational leadership $(M=2.89$, $\mathrm{S} . \mathrm{D}=1.34$ ) towards organisational culture in Libyan hotels is just average $(\mathrm{M}=2.96, \mathrm{~S} . \mathrm{D}=1.36)$.

Based on the above data, it can conclude that there is a weakness of organisational culture indicators, although, it was significant all indicators were below the acceptable average 4.00, it means that the managers have not concentrated enough on Dominant characteristics of organisational culture such as personal aspects of workers, dynamic and innovation. In addition, there is no enough encouragement to individuals for taking risks and introducing new and innovative ideas, and leadership, Staff Management, Organizational coherence, Strategic focus, and Standard of Excellence.

In general, this weakness is shaping obstacle to employees' conviction of organizational culture and to ensuring the importance of corporate culture between employees and customers. As well as, focusing on counselling, facilitation as fatherhood for all employees, supporting employees to be a pioneer, and encouraging employees to maximise the productivity and competitiveness and manages difficulties. Although all these elements are very important for supporting the coherence of organisational culture, they occupied a low concentrating from managers.

Vol. 28, No. 2 August 2020

(C) Centre for Indonesian Accounting and Management Research Postgraduate Program, Brawijaya University 


\section{Internal customer orientation:}

The following data in Table 3 representation description of respondents' answers including Mean, and standard deviation of internal customer orientation variable, which showed and obtained in table 3 .

\section{Table 3. Summary of descriptive data of VariableInternal customer} orientation

\begin{tabular}{|c|c|c|c|}
\hline \multirow{3}{*}{ Indicator } & Item & Mean & Std deviation \\
\hline \multirow{3}{*}{ Vision } & Believing of vision & 2.97 & 1.40 \\
\cline { 2 - 4 } & Clearance vision & 2.99 & 1.42 \\
\cline { 2 - 4 } & Reward & 3.00 & 1.49 \\
\hline Overall Vision & & $\mathbf{2 . 9 9}$ & $\mathbf{1 . 4 3}$ \\
\hline \multirow{3}{*}{ Development } & Training programs & 2.97 & 1.41 \\
\cline { 2 - 4 } & Collecting data & 2.94 & 1.38 \\
\cline { 2 - 4 } & Performance development & 2.83 & 1.38 \\
\cline { 2 - 4 } & Knowledge skills & 2.94 & 1.43 \\
\hline Overall Development & & $\mathbf{2 . 9 2}$ & $\mathbf{1 . 4 0}$ \\
\hline \multirow{2}{*}{ Rewards } & Encouragement & 3.22 & 1.43 \\
\cline { 2 - 4 } & Excellent services & 2.93 & 1.45 \\
\cline { 2 - 4 } & Communicating & 2.71 & 1.33 \\
\hline Overall Rewards & & $\mathbf{2 . 9 5}$ & $\mathbf{1 . 4 1}$ \\
\hline \multirow{2}{*}{ Dealings } & Administration dealing & 2.67 & 1.37 \\
\cline { 2 - 4 } & Employees services & 2.78 & 1.44 \\
\cline { 2 - 4 } & Collaborating & 2.90 & 1.42 \\
\hline Overall Dealings & $\mathbf{2 . 7 9}$ & $\mathbf{1 . 4 1}$ \\
\hline Overall Internal customer orientation & $\mathbf{2 . 9 1}$ & $\mathbf{1 . 4 1}$ \\
\hline
\end{tabular}

Based on the descriptive data in Table 3, Vision $(M=2.99$, S.D.=1.43) becomes the most important dimension in Internal customer orientation of hotels sector, followed by Rewards $(\mathrm{M}=2.95$, S.D.=1.41), and Development $(\mathrm{M}=2.92$, S.D. $=1.40)$. Meanwhile, Dealings $(\mathrm{M}=2.79$, S.D.=1.41) towards Internal customer orientation indicator is just average.

This finding indicates that most employees as internal customers believing the institution vision, and the mangers are offering workers a clear vision that they can believe in, as they are measuring employee performance and rewarding who has a large contribution to the hotel vision. In addition, internal customers may not believe the vision because of the unclear that may cover the policies of the administration.

Meanwhile, the training programmes for all employees to improve their services skills, and collect data from employees in order to develop the hotel strategy and the workers' jobs, it can be contributing to develop hotel programmes. As well as, the results indicate that of Rewards indicator is considers as a system to increase employee's performance and serving customers in high quality. As well as managers encouraging the staff to work as one team as it appeared in the data findings. However, communicating with 
employees and motivate them could be a well-suited way to increase their productivity and their loyalty to the firm.

Based on the answers from respondents regarding dealings indicator: The administration deals all department in the hotel as an independent customer, as data showed that the administration seeking to develop the quality of services providing to employees. Whereas, the collaboration between the departments can be lead to understanding and provide internal customer needs.

\section{Internal service quality}

The following data in Table 4 representation description of respondents' answers including Mean, and standard deviation of internal service quality variable, which showed and obtained in table 4.

\section{Table 5.4. Summary of descriptive data of VariableInternal service} quality

\begin{tabular}{|c|c|c|c|}
\hline Indicator & Item & Mean & Std deviation \\
\hline \multirow{3}{*}{ Assurance } & Feeling safe & 2.83 & 1.45 \\
\hline & Employees helping & 2.66 & 1.41 \\
\hline & Trust dealing & 2.80 & 1.36 \\
\hline \multicolumn{2}{|l|}{ Overall Assurance } & 2.76 & 1.41 \\
\hline \multirow{4}{*}{ Responsiveness } & Serving employees & 2.89 & 1.46 \\
\hline & Personal interest & 2.84 & 1.34 \\
\hline & Employees' requests & 2.95 & 1.46 \\
\hline & Promises & 2.61 & 1.37 \\
\hline \multicolumn{2}{|l|}{ Overall Responsiveness } & 2.82 & 1.41 \\
\hline \multirow{3}{*}{ Reliability } & Interests & 2.77 & 1.47 \\
\hline & Problems solving & 3.17 & 1.43 \\
\hline & Avoiding mistakes & 2.90 & 1.38 \\
\hline \multicolumn{2}{|l|}{ Overall Reliability } & 2.95 & 1.43 \\
\hline \multirow{4}{*}{ Empathy } & Contacting way & 2.92 & 1.39 \\
\hline & services promised & 2.78 & 1.36 \\
\hline & Solving problems timely & 2.84 & 1.42 \\
\hline & New services & 3.10 & 1.40 \\
\hline \multicolumn{2}{|l|}{ Overall Empathy } & 2.91 & 1.39 \\
\hline \multirow{3}{*}{ Tangibles } & Service equipment & 2.98 & 1.39 \\
\hline & Facilities & 3.08 & 1.41 \\
\hline & Quality equipment & 2.68 & 1.38 \\
\hline \multicolumn{2}{|l|}{ Overall Tangibles } & 2.91 & 1.40 \\
\hline \multicolumn{2}{|l|}{ Overall Internal service quality } & 2.87 & 1.41 \\
\hline
\end{tabular}

Based on the descriptive data in Table 4, Reliability $(\mathrm{M}=2.95$, S.D. $=1.43$ ) becomes the most important element in Internal service quality of Libyan hotels sector, followed by Tangibles $(M=2.91$, S.D.=1.40), and Empathy

Vol. 28, No. 2 August 2020

(C) Centre for Indonesian Accounting and Management Research Postgraduate Program, Brawijaya University 
( $\mathrm{M}=2.91$, S.D.=1.39). Meanwhile, Responsiveness $(\mathrm{M}=2.82$, S.D.=1.41), and Assurance $(\mathrm{M}=2.76$, S.D.=1.41), and the overall of internal service quality variable $(\mathrm{M}=2.87$, S.D. $=1.41)$.

according to the above data, it can conclude that, there is a weakness of internal service quality criteria, although, it was significant but all indicators were below the acceptable average 4.00, it means that the managers have not concentrated enough on internal service quality. Furthermore, this finding indicates that most administrations are caring for internal service quality such as assurance, where managers seek to maximize employees' feeling safe, the concentrating of solving problems facing workers. Confidence in dealing with employees and non-discrimination between them only through the completion of the work between both them only through the completion of the work according to their abilities and their skills.

Meantime, the concentrate of managers on these effective elements helps to improve the level of assurance for the services provided to employees as internal customers. In addition, regarding responsiveness: data indicates that hotel administration spends the time required to serve employees, and focused on personal interest with each employee, as managers work to fulfil their promises with employees on time. Additionally, most of the managers interested in the employees' interests, address the problems they may happen in one of the departments, avoiding mistakes with staff.

As well as, table 5.4 showed that hotel administration communicates with employees in a polite manner, and the administration always informs employees about new services available. Also providing new equipment that helps achieve works for employees and clients. However, data showed low mean level with the only $M=2.87$, S.D.= 1.41 , it means that there was a clear weakness of the internal quality service, even it was significant but below 4.0, which means quality of internal services is less than employees expectation.

\section{External Customer satisfaction Orientation}

The following data in Table 5 representation description of respondents' answers including Mean, and standard deviation of Customer satisfaction orientation variable, which showed and obtained in table 5.

Table 5. Summary of descriptive data of Variable Customer satisfaction Orientation

\begin{tabular}{|c|c|c|c|}
\hline Indicator & Item & Mean & Std deviation \\
\hline \multirow{2}{*}{ Attention to after- sales service } & Strategic goal & 2.81 & 1.44 \\
\cline { 2 - 4 } & Attention & 2.96 & 1.43 \\
\hline Overall Attention to after- sales service & & $\mathbf{2 . 8 8}$ & $\mathbf{1 . 4 3}$ \\
\hline \multirow{2}{*}{ Measuring strategies } & Examining CS & 3.01 & 1.47 \\
\cline { 2 - 4 } & Developing CS & 2.88 & 1.46 \\
\hline
\end{tabular}

Vol. 28, No. 2 August 2020

(C) Centre for Indonesian Accounting and Management Research

Postgraduate Program, Brawijaya University 


\begin{tabular}{|c|c|c|c|}
\hline \multicolumn{2}{|l|}{ Overall Measuring strategies } & 2.94 & 1.46 \\
\hline \multirow{2}{*}{ Attention to customer satisfaction } & Additional services & 2.81 & 1.46 \\
\hline & additional SQ & 2.86 & 1.49 \\
\hline \multicolumn{2}{|l|}{ Overall Attention to customer satisfaction } & 2.83 & 1.47 \\
\hline \multirow{2}{*}{ Customer service } & Measuring services & 2.87 & 1.47 \\
\hline & Measurement tools & 2.94 & 1.58 \\
\hline \multicolumn{2}{|l|}{ Overall Customer service } & 2.90 & 1.52 \\
\hline \multicolumn{2}{|l|}{ Overall External customer satisfaction } & 2.89 & 1.47 \\
\hline
\end{tabular}

Based on the descriptive data in Table 3, Measuring strategies ( $M=2.94$, S.D.=1.46) becomes the most important element of the External customer satisfaction in Libyan hotels sector, followed by Customer service $(M=2.90$, S.D.=1.52), and Empathy $(\mathrm{M}=2.91$, S.D.=1.39). Meanwhile, Attention to aftersales service $(\mathrm{M}=2.88$, S.D. $=1.43)$, and Attention to customer satisfaction $(\mathrm{M}=2.83$, S.D. $=1.41)$, and the overall of External customer satisfaction variable $(\mathrm{M}=2.89$, S.D. $=1.47)$.

Based on the findings regarding attention to after-sales service. Managers see that Customer satisfaction is the first objective of our long-term strategy. Moreover, because of the importance of customer satisfaction, managers are giving full attention to customer relationship marketing. While the answers of other respondents varied greatly. In addition, measuring customer satisfaction frequently is considered as a suitable tool to ensure customers continuing deal with the hotel.

As well as, the above table showed that that mean average of external customer satisfaction indicators: Attention to after-sales, service measuring strategies, and Customer service with average (2.9\%) respectively. Whereas, Attention to customer satisfaction with the lowest percentage which as $(2.7 \%)$. Which resulted the average of external customer satisfaction with (2.9\%), and the overall of the variable external customer satisfaction is 2.89 , it means that the policies of most managers were below the expectations of customers, which depends on the quality of service provided.

\section{Hypothesis Testing}

TableT Statistics of Hypothesis

\begin{tabular}{|c|c|c|c|}
\hline Hypothesis & Statement & T Statistics & description \\
\hline H1 & $\begin{array}{c}\text { Organizational Culture on External customer } \\
\text { satisfaction orientation }\end{array}$ & 2.945 & Supported \\
\hline H2 & $\begin{array}{c}\text { Organizational Culture on Internal customer } \\
\text { orientation }\end{array}$ & 5.723 & Supported \\
\hline
\end{tabular}

Vol. 28, No. 2 August 2020

(C) Centre for Indonesian Accounting and Management Research Postgraduate Program, Brawijaya University 


\begin{tabular}{|c|c|c|c|}
\hline H3 & $\begin{array}{c}\text { Organizational Culture on Internal Service } \\
\text { Quality }\end{array}$ & 3.997 & Supported \\
\hline H4 & $\begin{array}{c}\text { Internal customer orientation on External } \\
\text { customer satisfaction orientation }\end{array}$ & 4.120 & Supported \\
\hline H5 & $\begin{array}{c}\text { Internal Service Quality on External customer } \\
\text { satisfactionorientation }\end{array}$ & 2.250 & Supported \\
\hline
\end{tabular}

Hypothesis testing is done by the bootstrap resampling method developed by Geisser and Stone. Statistical test used is the statistic t or T test. Application of resampling methods, allowing free entry into force of the distributed data (distribution free), does not require the assumption of a normal distribution, and does not require a large sample. Testing is done by $\mathrm{t}-$ statistic, when obtained t- statistic $>\mathrm{t}$-table, then concluded significantly, and vice versa. When the results of testing hypothesis on models outer significantly, it indicates that the indicator is viewed can be used as a measuring instrument latent variables. Meanwhile, when the test results in inner models is significant, it means that there is a significant effect of latent variables to other latent variables.

Note: ${ }^{*}=$ significant

Figure 2. Path diagram (second running by PLS).

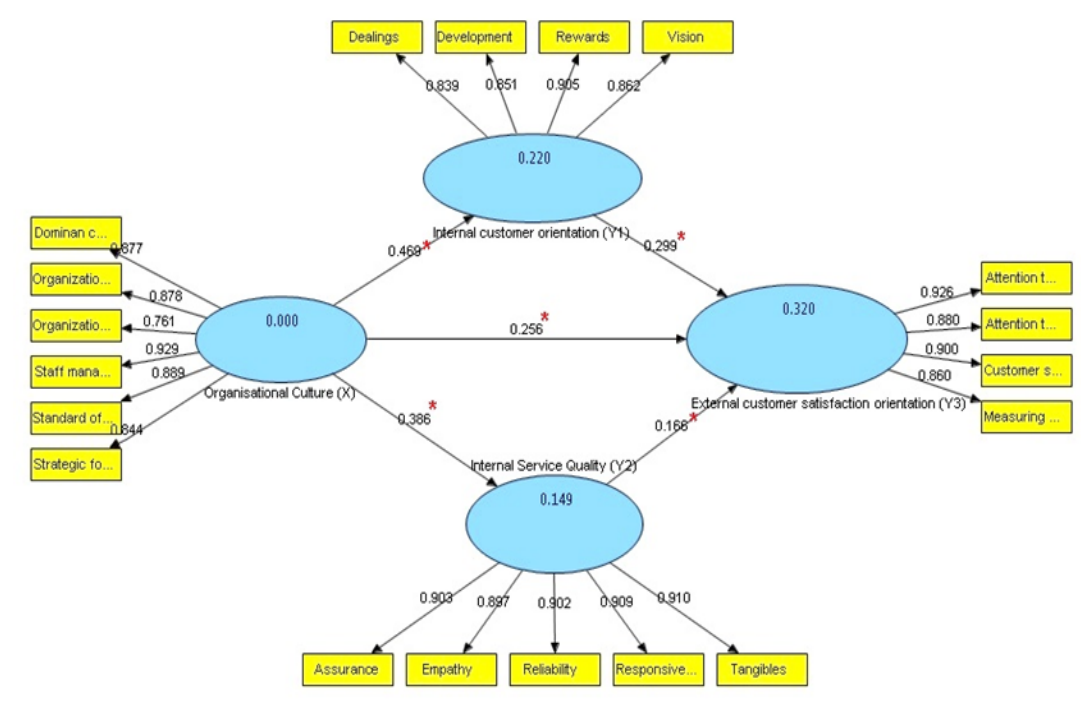

To test the hypothesis, we can see the value of t-statistics. Limits to reject and accept the hypothesis put forward is 1.96 ( $\mathrm{t}$ table). Where if the value 
$\mathrm{t}$ statistics is in the range of tables and values $\mathrm{t}$ table then the hypothesis will be rejected or, in other words accept the null hypothesis (H0).

Based on the above analyse results it could summarize the following:

1. The estimation results of inner model for the direct effect of Organizational Culture (X) to External customer satisfaction orientation (Y3) shows the value of $\mathrm{t}$-statistics for 2.945, where the value is greater than 1.96 with error level $\alpha=5 \%$, so this indicates there is a significant direct effect between Organizational Culture $(\mathrm{X})$ to External customer satisfaction orientation (Y3) by loading factor 0.256 . The positive influence between Organizational Culture $(\mathrm{X})$ to External customer satisfaction orientation (Y3)can be interpreted that the higher Organizational Culture (X), then it will be followed by an increase External customer satisfaction orientation (Y3). Moreover, vice versa, the worse Organizational Culture (X) then this will decrease External customer satisfaction orientation (Y3).

2. The estimation results of inner model for the direct effect of Organizational Culture $(\mathrm{X})$ to Internal customer orientation (Y1) shows the value of $\mathrm{t}$ statistics for 5.723, where the value is greater than 1.96 with error level $\alpha=$ $5 \%$, so this indicates there is a significant direct effect between Organizational Culture (X) to Internal customer orientation (Y1) by loading factor 0.469. The positive influence between Organizational Culture $(\mathrm{X})$ to Internal customer orientation (Y1) can be interpreted that the higher Organizational Culture (X), then it will be followed by an increase Internal customer orientation (Y1). And vice versa, the worse Organizational Culture $(\mathrm{X})$ then this will decrease Internal customer orientation (Y1).

3. The estimation results of inner model for the direct effect of Organizational Culture (X) to Internal Service Quality (Y2) shows the value of $\mathrm{t}$-statistics for 3.997, where the value is greater than 1.96 with error level $\alpha=5 \%$, so this indicates there is a significant direct effect between Organizational Culture $(\mathrm{X})$ to Internal Service Quality (Y2) by loading factor 0.386. The positive influence between Organizational Culture (X) to Internal Service Quality (Y2) can be interpreted that the higher Organizational Culture (X), then it will be followed by an increase Internal Service Quality (Y2). And vice versa, the worse Organizational Culture $(\mathrm{X})$ then this will decrease Internal Service Quality (Y2).

4. The estimation results of inner model for the direct effect of Internal customer orientation (Y1) to External customer satisfaction orientation (Y3) shows the value of $\mathrm{t}$-statistics for 4.120 , where the value is greater than 1.96 with error level $\alpha=5 \%$, so this indicates there is a significant direct effect between Internal customer orientation (Y1) to External customer satisfaction orientation (Y3) by loading factor 0.299 . The positive influence between Internal customer orientation (Y1) to External customer

Vol. 28, No. 2 August 2020

(C) Centre for Indonesian Accounting and Management Research Postgraduate Program, Brawijaya University 
satisfaction orientation (Y3) can be interpreted that the higher Internal customer orientation (Y1), then it will be followed by an increase External customer satisfaction orientation (Y3). And vice versa, the worse Internal customer orientation (Y1) then this will decrease External customer satisfaction orientation (Y3).

5. The estimation results of inner model for the direct effect of Internal Service Quality (Y2) to External customer satisfaction orientation (Y3) shows the value of $\mathrm{t}$-statistics for 2.250, where the value is greater than 1.96 with error level $\alpha=5 \%$, so this indicates there is a significant direct effect between Internal Service Quality (Y2) to External customer satisfaction orientation (Y3) by loading factor 0.166 . The positive influence between Internal Service Quality (Y2) to External customer satisfaction orientation (Y3) can be interpreted that the higher Internal Service Quality (Y2), then it will be followed by an increase External customer satisfaction orientation (Y3). And vice versa, the worse Internal Service Quality (Y2) then this will decrease External customer satisfaction (Y3).

The indirect effect between Organizational Culture $(\mathrm{X})$ to External customer satisfaction orientation (Y3) through Internal customer orientation (Y1)

Testing the hypothesis for indirect effects was carried out by the SOBEL test, as follows.

$\mathrm{a}=$ Organizational Culture $(\mathrm{X})$ route to Internal customer orientation $(\mathrm{Y} 1)=0.469$

$\mathrm{b}=$ Internal customer orientation (Y1) route to External customer satisfaction orientation $(\mathrm{Y} 3)=0.299$

$\mathrm{ab}=($ Organizational Culture $(\mathrm{X})$ route to Internal customer orientation (Y1)) * (Internal customer orientation (Y1) route to External customer satisfaction orientation $(\mathrm{Y} 3))=0.469 * 0.299=0.140$

$\mathrm{Sa}=$ standard error Organizational Culture $(\mathrm{X})$ route to Internal customer orientation $(\mathrm{Y} 1)=0.082$

$\mathrm{Sb}=$ standard error Internal customer orientation route to External customer satisfaction orientation $=0.073$

$$
\begin{gathered}
\mathrm{Sab}=\sqrt{b^{2} S a^{2}+a^{2} S b^{2}+S a^{2} S b^{2}} \\
\mathrm{Sab} \\
\sqrt{(0.299)^{2}(0.082)^{2}+(0.469)^{2}(0.073)^{2}+(0.082)^{2}(0.073)}=0.042
\end{gathered}
$$

Then to test the significance of indirect effects, it is necessary to calculate the value of $t$ from the ab coefficient as follows.

$$
t=\frac{a b}{S a b}=\frac{0.140}{0.042}=3.311
$$

The path coefficient value for the indirect effect of Organizational Culture (X) to External customer satisfaction orientation (Y3) through Internal 
customer orientation (Y1) is 0.140 which shows that the statistical $t$ value is 3.311 which is above \pm 1.96 (5\%), so it can be concluded that Organizational Culture's influence to External customer satisfaction orientation (Y3) through Internal customer orientation (Y1) is significant. In other words, the magnitude of Organizational Culture's influence caused by the presence of internal customer orientation (Y1) has a real positive effect to External customer satisfaction orientation (Y3), where the greater Organizational Culture caused by the presence of Internal customer orientation (Y1), the more it will improve External customer satisfaction orientation (Y3). Likewise the opposite.

2. For indirect effect between Organizational Culture (X) to External customer satisfaction orientation (Y3) through Internal Service Quality (Y2)

Testing the hypothesis for indirect effects was carried out by the SOBEL test, as follows.

$\mathrm{a}=$ Organizational Culture $(\mathrm{X})$ route to Internal Service Quality $(\mathrm{Y} 2)=$ 0.386

$\mathrm{b}=$ Internal Service Quality (Y2) route to External customer satisfaction $(\mathrm{Y} 3)=0.166$

$\mathrm{ab}=($ Organizational Culture $(\mathrm{X})$ route to Internal Service Quality $(\mathrm{Y} 2))$ * (Internal Service Quality $(\mathrm{Y} 2)$ route to External customer satisfaction $(\mathrm{Y} 3))=$ $0.386 * 0.166=0.064$

$\mathrm{Sa}=$ standard error Organizational Culture $(\mathrm{X})$ route to Internal Service Quality (Y2) $=0.087$

$\mathrm{Sb}=$ standard error Internal Service Quality (Y2) route to External customer satisfaction $=0.074$

$$
\begin{aligned}
& \mathrm{Sab}=\sqrt{b^{2} S a^{2}+a^{2} S b^{2}+S a^{2} S b^{2}} \\
& \mathrm{Sab} \\
& \sqrt{(0.166)^{2}(0.087)^{2}+(0.386)^{2}(0.074)^{2}+(0.087)^{2}(0.074)}=0.032
\end{aligned}
$$

Then to test the significance of indirect effects, it is necessary to calculate the value of $\mathrm{t}$ from the ab coefficient as follows.

$$
t=\frac{a b}{S a b}=\frac{0.064}{0.032}=1.969
$$

The path coefficient value for the indirect effect of Organizational Culture (X) to External customer satisfaction orientation (Y3) through Internal Service Quality (Y2) is 0.064 which shows that the statistical t value is 1.969 which is above $\pm 1.96(5 \%)$, so it can be concluded that Organizational Culture's influence to External customer satisfaction orientation (Y3) through Internal Service Quality (Y2) is significant. In other words, the magnitude of Organizational Culture's influence caused by the presence of Internal Service Quality (Y2) has a real positive effect to External customer satisfaction orientation (Y3), where the greater Organizational Culture caused by the

Vol. 28, No. 2 August 2020 (C) Centre for Indonesian Accounting and Management Research Postgraduate Program, Brawijaya University 
presence of Internal Service Quality (Y2), the more it will improve External customer satisfaction orientation (Y3). Likewise the opposite.

\section{Conclusion}

Based on the analysis described in the previous chapter that the research on Libyan hotels that have listed on the Libyan ministry of tourism can summarized as follows:

In conclusion, 'Organizational coherence' becomes the most important criteria in the organisational culture of hotels administrations, followed by other factors (i.e. Organizational leadership, Staff management, Organizational coherence, Strategic focus, Standard of excellence and etc.). The result of this study also shows the association between almost all mediating variables and organisational culture towards private hotels. Further examination of these associations indicates that the most significant factor that influences internal customer orientation of the hotel organisations are Vision, Development, rewards and dealings. Another significant finding of this study signifies that external customer satisfaction is influences by their perception toward the quality of services provided and how the hotel can fulfil their requirements.

This finding may assist hotels managersto better understandingthe factors of organisational culture influencing consumers' satisfaction through improving the standard of the concentrating on internal customer orientation and indirectly improve the internal service quality in local hotels. Furthermore, it also adds new knowledge to the public on the meaning of organisational culture and client satisfaction.

Indeed, this research has more contributions for improving customer satisfaction. Further research could be conduct to a different segment of consumers or other service sectors so that the result may be reflective of the actual culture of organisations in Libya.

Although this study has proposed that internal customer orientation and internal service quality (intrinsic factor) may affect consumers' satisfaction through efficient organisational culture, other factors have vital importance to comprehend consumers satisfaction. Including more factors related to firms' behaviour of their cultures to study customer expectations and their real attitudes toward an organisational culture of the service sector. 


\section{REFERENCES}

Abridah, A. I. A. (2012). The Influence of National and Organisational Culture on Creativity in Libyan Work Environments. The University of Huddersfield.

Abubaker, A. (2007). Influence of core cultural values on the communication behaviour of staff in Libyan organisation. Research Paper, Annual Review of Education, Communication \& Language Science, ARECLS, 4.

Agbejule, A. (2011). Organizational culture and performance: the role of management accounting system. Journal of Applied Accounting Research, 12(1), 74-89.

Ahmed, P. K., \& Rafiq, M. (2003). Internal marketing issues and challenges. European Journal of Marketing, 37(9), 1177-1186.

Alshibani, E., \& Alatwi, A. A. (2010). Measurement of organizational culture and diagnosis of the gap in educational institutions applied study at the University of Karbala. Qadisiyah Journal of Administrative and Economic Sciences, 12(4), 37-65.

Ambrož, M., \& Praprotnik, M. (2008). Organisational effectiveness and customer satisfaction. Organizacija, 41(5), 161-173.

Amiri Aghdaie, S., \& Faghani, F. (2012). Mobile banking service quality and customer satisfaction (application of SERVQUAL model). International Journal of Management and Business Research, 2(4), 351-361.

Anosike, U. P., \& Eid, R. (2011). Integrating internal customer orientation, internal service quality, and customer orientation in the banking sector: An empirical study. The Service Industries Journal, 31(14), 24872505.

Bass, B. M., Stogdill, R. M., \& Bass, R. R. (2008). Stogdill's handbook of leadership: A survey of theory and research: free press.

Baumann, C., Elliott, G., \& Burton, S. (2012). Modeling customer satisfaction and loyalty: survey data versus data mining. Journal of Services Marketing, 26(3), 148-157.

Bellou, V. (2007). Achieving long-term customer satisfaction through organizational culture: Evidence from the health care sector. Managing Service Quality: An International Journal, 17(5), 510-522.

Bitsani, E. (2013). Theoretical approaches to the organizational culture and the organizational climate: Exploratory research examples and best policies in health care services. Journal of Human Resource Management, 1(4), 48-58.

Vol. 28, No. 2 August 2020

(C) Centre for Indonesian Accounting and Management Research Postgraduate Program, Brawijaya University 
Bizi Mubiri, J. (2016). Customer Satisfaction in Hotel Services.

Bowen, J. T., \& Chen, S.-L. (2001). The relationship between customer loyalty and customer satisfaction. International Journal of Contemporary Hospitality Management, 13(5), 213-217.

Cameron, K. (2018). Organizational Culture Assessment Instrument online. In O. Online (Ed.), https://www.ocai-online.com/about-theOrganizational-Culture-Assessment-Instrument-OCAI/OCAl-Assessment (Vol. 2018). webpage: OCIA Online.

Conrad, C. A., Brown, G., \& Harmon, H. A. (1997). Customer satisfaction and corporate culture: A profile deviation analysis of a relationship marketing outcome. Psychology \& Marketing, 14(7), 663-674.

Davidson, M. (2008). Internal marketing. Handbook of hospitality marketing management, 473-500.

Davidson, M. C. (2003). Does organizational climate add to service quality in hotels? International Journal of Contemporary Hospitality Management, 15(4), 206-213.

Day, G. S. (1994). The capabilities of market-driven organizations. Journal of marketing, 58(4), 37-52.

Deshpandé, R., \& Farley, J. U. (1999). Executive insights: corporate culture and market orientation: comparing Indian and Japanese firms. Journal of International Marketing, 7(4), 111-127.

Desson, K., \& Clouthier, J. (2010). Organizational culture-why does it matter. Paper presented at the Symposium on International Safeguards International Atomic Energy Agency Vienna, Austria.

Ehrhart, M. G., Schneider, B., \& Macey, W. H. (2013). Organizational climate and culture: An introduction to theory, research, and practice: Routledge.

Fattah, S., \& Twigg, D. (2017). The impact of internal marketing and organisational culture mediated by organisational commitment on operational performance.

Ferreira, M. P., \& Li, D. (2010). Transactions Cost Theory influence in strategy research: A review through a bibliometric study in leading journals.

Gillespie, M. A., Denison, D. R., Haaland, S., Smerek, R., \& Neale, W. S. (2008). Linking organizational culture and customer satisfaction: Results from two companies in different industries. European Journal of work and organizational psychology, 17(1), 112-132.

Hofstede, G. (1980). Culture and organizations. International Studies of Management \& Organization, 10(4), 15-41. 
Hofstede, G. (2001). Culture's recent consequences: Using dimension scores in theory and research. International Journal of cross cultural management, 1(1), 11-17.

Hofstede, G. (2018, February 25, 2014). Organisational Culture. Retrieved from https://www.quickbase.com/blog/6-dimensions-oforganizational-culture-which-one-is-right-for-you

Hofstede, G., Hofstede, G. J., \& Minkov, M. (2010). Intercultural cooperation and its importance for survival, Nueva York: McGraw Hill.

Homburg, C., Müller, M., \& Klarmann, M. (2011). When should the customer really be king? On the optimum level of salesperson customer orientation in sales encounters. Journal of marketing, 75(2), 55-74.

Horowitz, D. M. (2009). A review of consensus analysis methods in consumer culture, organizational culture and national culture research. Consumption, Markets and Culture, 12(1), 47-64.

House, R. J., \& Podsakoff, P. M. (2013). Leadership effectiveness: Past perspectives and future directions for research Organizational behavior (pp. 55-92): Routledge.

Huber, G. P., \& Power, D. J. (1985). Retrospective reports of strategic-level managers: Guidelines for increasing their accuracy. Strategic management journal, 6(2), 171-180.

Hughes, J. (2015). Looking elsewhere: Howard S. Becker as unwilling organisational theorist. Organization, 22(6), 769-787.

Järvi, S. (2012). Developing the Internal Service Quality in Organisation Y.

Jun, M., \& Cai, S. (2010). Examining the relationships between internal service quality and its dimensions, and internal customer satisfaction. Total Quality Management, 21(2), 205-223.

Kao, C.-Y., Tsaur, S.-H., \& Wu, T.-C. E. (2016). Organizational culture on customer delight in the hospitality industry. International Journal of Hospitality Management, 56, 98-108.

Kim Jean Lee, S., \& Yu, K. (2004). Corporate culture and organizational performance. Journal of managerial psychology, 19(4), 340-359.

Kotler, P., \& Keller, K. L. (2009). Marketing Management 13th Edition, New Jersey: Person Education: Inc.

Kummerow, E., \& Kirby, N. (2013). Organisational Culture: Concept, Context, and Measurement (In Two Volumes). World Scientific Books.

Lim, L. (2002). National culture and organizational behavior of Malaysian and Japanese firms. Innovation, 4(1-3), 88-98.

Vol. 28, No. 2 August 2020

(C) Centre for Indonesian Accounting and Management Research Postgraduate Program, Brawijaya University 
Makeeva, E. (2010). Service quality and customer satisfaction: case: Restel Hotels in Imatra and Lappeenranta.

Narver, J. C., \& Slater, S. F. (1990). The effect of a market orientation on business profitability. Journal of marketing, 54(4), 20-35.

Pantouvakis, A., \& Bouranta, N. (2013). The link between organizational learning culture and customer satisfaction: Confirming relationship and exploring moderating effect. The Learning Organization, 20(1), 48-64.

Pantouvakis, A., \& Mpogiatzidis, P. (2013). The impact of internal service quality and learning organization on clinical leaders' job satisfaction in hospital care services. Leadership in Health Services, 26(1), 34-49.

Senarathna, I., Warren, M., Yeoh, W., \& Salzman, S. (2014). The influence of organisation culture on E-commerce adoption. Industrial Management \& Data Systems, 114(7), 1007-1021.

Sharp, B. (2013). Marketing: theory, evidence, practice. Australia: Oxford University Press.

Srivastava, S., \& Prakash, G. (2019). Internal Service Quality: Insights from Healthcare Sector. Journal of Health Management, 21(2), 294-312.

Susanti, E., Sule, E., \& Sutisna, H. (2015). The Impact of Internal and External Service Quality (A Case Study among Lecturers and Students).

Susanti, E., Sule, E. T., \& Sutisna, H. (2015). The impact of internal and external service quality (A case study among lecturers and students). Mediterranean Journal of Social Sciences, 6(5 S5), 77.

Tsoukatos, E., \& Rand, G. K. (2007). Cultural influences on service quality and customer satisfaction: evidence from Greek insurance. Managing Service Quality: An International Journal, 17(4), 467-485.

Varey, R. J., \& Lewis, B. R. (2000). Internal marketing: directions for management: Psychology Press.

Wang, G.-L. (2012a). The influence of internal service quality on employee job satisfaction at Taiwan-listed international tourist hotels: Using organisational culture as the moderator. World Transactions on Engineering and Technology Education, 10(3), 174-183.

Wang, G.-L. (2012b). A Study of How the Organizational Culture of International Tourist Hotels Affects Organizational Performance: Using Intellectual Capital as the Mediating Variable. Journal of Global Business Management, 8(1), 189.

Webster Jr, F. E. (1988). The rediscovery of the marketing concept. Business horizons, 31(3), 29-39. 
Weeks, J., \& Galunic, C. (2003). A theory of the cultural evolution of the firm: The intra-organizational ecology of memes. Organization Studies, 24(8), 1309-1352.

Willcoxson, L., \& Millett, B. (2000). The management of organisational culture. Australian Journal of Management and Organisational Behaviour, 3(2), 91-99.

Wilson, A. (2002). Attitudes towards customer satisfaction measurement in the retail sector. International Journal of Market Research, 44(2), 213.

Vol. 28, No. 2 August 2020

(C) Centre for Indonesian Accounting and Management Research Postgraduate Program, Brawijaya University 